\title{
THE CONCEPTUAL FRAMEWORK FOR THE FORMATION OF A RISK-BASED SYSTEM FOR COMBATING MONEY LAUNDERING, TERRORIST FINANCING, AND THE FINANCING OF THE PROLIFERATION OF WEAPONS OF MASS DESTRUCTION*
}

\author{
๑) 2018 VNUKOVA N. M., ANDRIICHENKO ZH. O., HONTAR D. D.
}

UDC 338.22.021.4

JEL Classification: G28; G32

\author{
Vnukova N. M., Andriichenko Zh. O., Hontar D. D.
}

The Conceptual Framework for the Formation of a Risk-Based System for Combating Money Laundering, Terrorist Financing, and the Financing of the Proliferation of Weapons of Mass Destruction

The aim of the article is to elaborate the theoretical basis for the development of conceptual framework for implementing a risk-based system for combating money laundering, terrorist financing, and the financing of the proliferation of weapons of mass destruction. The list of regulatory documents which are of strategic nature for the functioning of the AML / CFT system in Ukraine is studied. The sequence of development of the Concept for the formation of a risk-based AML / CFT system is proposed. The recommendations of international organizations on the adoption of a risk-based AML / CFT system when using payment cards, mobile payments, and Internet-based payment services, in particular, through commercial websites and Internet payment systems; carrying out transactions with virtual assets, in the work of banks; countering the financing of terrorism, providing monetary services, in real estate transactions. It is proposed to use the system, institutional and functional approaches as a methodological basis for the Concept of the formation of a risk-based AML / CFT system. Hypotheses concerning the formation of the risk-based AML / CFT system are put forward, their verification is carried out, and methods for their proof are substantiated. The basic principles of the formation of a risk-based AML / CFT system are described, and based of them the Conceptual framework for the current development of a risk-based AML / CFT system are formed. The priority directions of the functioning and development of the risk-based AML / CFT system in Ukraine are identified.

Keywords: international standards, risk-based system, money laundering, financing of terrorism and proliferation of weapons of mass destruction.

DOI: https://doi.org/10.32983/2222-0712-2018-4-201-215

Fig.: 4. Tbl.: 2. Bibl.: 35 .

Vnukova Nataliya M. - Doctor of Sciences (Economics), Professor, Head of the Department of Management of Financial Services, Simon Kuznets Kharkiv National University of Economics (9a Nauky Ave., Kharkiv, 61166, Ukraine)

E-mail: ufp2007@meta.ua

ORCID: 0000-0002-1354-4838

Researcher ID: T-9097-2018

Andriichenko Zhanna 0. - Candidate of Sciences (Economics), Associate Professor, Associate Professor of the Department of Financial Services Management, Simon Kuznets Kharkiv National University of Economics (9a Nauky Ave., Kharkiv, 61166, Ukraine)

E-mail: zhanna.andriichenko@hneu.net

ORCID: 0000-0003-2061-0036

Hontar Daria D. - Candidate of Sciences (Economics), Lecturer, Department of Management of Financial Services, Simon Kuznets Kharkiv National University of Economics (9a Nauky Ave., Kharkiv, 61166, Ukraine)

E-mail: ddgontar@i.ua

ORCID: 0000-0001-5416-9328

Researcher ID: C-9917-2017

УДК 338.22.021.4

JEL Classification: G28; G32

Внукова Н. М., Андрійченко Ж. О., Гонтар Д. Д. Концептуальні засади формування ризик-орієнтованої системи протидії відмиванню коштів, фінансуванню тероризму та розповсюдженню зброї масового знищення

Метою статті є розробка теоретичних положень щодо формування концептуальних засад із запровадження ризик-орієнтованої системи протидії відмиванню коштів, фінансуванню тероризму та розповсюдженню зброї масового знищення. Досліджено перелік нормативних документів, що мають стратегічний характер для функціонування системи забезпечення протидії ВК / ФТРЗ в Україні. Запропоновано
УДК 338.22.021.4

JEL Classification: G28; G32

Внукова Н. Н., Андрейченко Ж. О., Гонтарь Д. Д. Концептуальные основы формирования риск-ориентированной системы противодействия отмыванию денег, финансированию терроризма и распространению оружия массового уничтожения

Целью статьи является разработка теоретических положений по формированию концептуальных принципов внедрения рискориентированной системы противодействия отмыванию денег, финансированию терроризма и распространению оружия массового уничтожения. Исследован перечень нормативных документов, имеющих стратегический характер для функционирования систе-

*The study was carried out in the framework of the fundamental research "A risk-based approach to combating money laundering, terrorist financing, and the financing of the proliferation of weapons of mass destruction» No. 54 / 2018-2020 (the state registration number 0118U000058) 
послідовність розробки Концепції формування ризик-орієнтованої системи забезпечення протидії ВК / ФТРЗ. Узагальнено рекомендачії міжнародних організацій щодо запровадження ризик-орієнтованої системи забезпечення протидії ВК / ФТРЗ при застосовуванні платіжних карток, мобільних платежів і послуг онлайн-платежів, зокрема, через комерційні веб-сайти та платіжні системи Інтернету, використанні віртуальних активів, у роботі банків, протидії фінансуванню тероризму, наданні грошових послуг, операціях з нерухомістю. Запропоновано використовувати системний, інституціональний та функціональний підходи як методологічну основу концепиії формування ризикорієнтованої системи забезпечення протидії ВК / ФТРз. Висунуто гіпотези формування ризик-орієнтованої системи забезпечення протидії ВК / ФТРЗ та здійснено їхню перевірку, обгрунтовано методи їх доведення. Описано основні принципи формування ризик-орієнтованої системи протидії ВК / ФТРЗ та з урахуванням чього сформовано Концептуальні засади сучасного розвитку ризик-орієнтованої системи забезпечення протидії ВК / ФТРЗ. Визначено пріоритетні напрями функиіонування та розвитку ризик-орієнтованої системи забезпечення протидії ВК / ФТРЗ України.

Ключові слова: міжнародні стандарти, ризик-орієнтована система, відмивання грошей, фінансування тероризму та розповсюдження зброї масового ураження.

Рис.: 4. Табл.: 2. Бібл.: 35.

Внукова Наталя Миколаївна - доктор економічних наук, професор, завідувач кафедри управління фінансовими послугами, Харківський начіональний економічний університет ім. С. Кузнеця (просп. Науки, 9a, Харків, 61166, Україна)

E-mail: ufp2007@meta.ua

ORCID: 0000-0002-1354-4838

Researcher ID: T-9097-2018

Андрійченко Жанна Олегівна - кандидат економічних наук, доцент, дочент кафедри управління фінансовими послугами, Харківський начіональний економічний університет ім. С. Кузнеця (просп. Науки, 9a, Харків, 61166, Україна)

E-mail: zhanna.andriichenko@hneu.net

ORCID: 000-0003-2061-0036

Гонтар Дар'я Дмитрівна - кандидат економічних наук, викладач, кафедра управління фінансовими послугами, Харківський національний економічний університет ім. С. Кузнеия (просп. Науки, 9а, Харків, 61166, Україна)

E-mail:ddgontar@i.ua

ORCID: 0000-0001-5416-9328

Researcher ID: C-9917-2017 мы обеспечения противодействия ОД / ФТРО в Украине. Предложена последовательность разработки Концепции формирования рискориентированной системы обеспечения противодействия ОД / ФТРО. Обобщены рекомендации международных организаций по внедрению риск-ориентированной системы обеспечения противодействия ОД / ФТРО при применении платежных карточек, мобильных платежей и услуг онлайн-платежей, в частности, через коммерческие вебсайты и платежные системы Интернета, использование виртуальных активов, в работе банков, противодействии финансированию терроризма, предоставлении денежных услуг, операциях с недвижимостью. Предложено использовать системный, институциональный и функциональный подходы как методологическую основу концепции формирования риск-ориентированной системы обеспечения противодействия ОД / ФТРО. Выдвинуты гипотезы формирования рискориентированной системы обеспечения противодействия ОД / ФТРО, и осуществлена их проверка, обоснованы методы их доказательства. Описаны основные принципы формирования риск-ориенттированной системы противодействия ОД / ФТРО, и с учетом этого сформированы Концептуальные основы современного развития рискориентированной системы обеспечения противодействия ОД / ФТРО. Определены приоритетные направления функционирования и развития риск-ориентированной системы обеспечения противодействия ОД / ФТРО Украины.

Ключевые слова: международные стандарты, риск-ориентированная система, отмывание денег, финансирование терроризма и распространение оружия массового поражения.

\section{Рис.: 4. Табл.: 2. Библ.: 35.}

Внукова Наталья Николаевна - доктор экономических наук, профессор, заведующий кафедрой управления финансовыми услугами, Харьковский национальный экономический университет им. С. Кузнеща (просп. Науки, 9а, Харьков, 61166, Украина)

E-mail:ufp2007@meta.ua

ORCID: 0000-0002-1354-4838

Researcher ID: T-9097-2018

Андрейченко Жанна Олеговна-кандидатэкономических наук, доцент, дочент кафедры управления финансовыми услугами, Харьковский национальный экономический университет им. С. Кузнеца (просп. Науки, 9а, Харьков, 61166, Украина)

E-mail: zhanna.andriichenko@hneu.net

ORCID: 0000-0003-2061-0036

Гонтарь Дарья Дмитриевна - кандидат экономических наук, преподаватель, кафедра управления финансовыми услугами, Харьковский национальный экономический университет им. С. Кузнеца (просп. Науки, 9а, Харьков, 61166, Украина)

E-mail: ddgontar@i.ua

ORCID: 0000-0001-5416-9328

Researcher ID: C-9917-2017
Introduction. The application of a risk-based approach to reporting entities (REs) [2] and the formation of a risk-based system for combating money laundering, terrorist financing, and the financing of the proliferation of weapons of mass destruction is a necessary requirement of the international standards set by the FATF [17].

According to the FATF International Standards on Combating Money Laundering and the Financing of Terrorism \& Proliferation (2012) [17], the policy on and coordination of anti-money laundering and countering the financing of terror- ism (AML / CFT) concern assessing relevant risks and applying the risk-based approach. A country must identify, assess, and understand the risks to its financial system to form its national policy and develop measures to counteract them.

Money laundering (ML), terrorist financing (TF), and the financing of the proliferation of weapons of mass destruction (PW) are significant threats to the global security and integrity of the financial system, and the FATF International Standards (FATF Recommendations) are intended to protect against them [17]. 
One of the main accents of the new report, published on January 30, 2018 by MONEYVAL experts [19], is that Ukraine has problems with collecting information on financial frauds and crimes: government structures are aware of the facts revealed but do not use them as the basis for criminal proceedings. Therefore, creating the basis of the concept of a risk-based system for combating money laundering, terrorist financing, and the financing of the proliferation of weapons of mass destruction is an urgent task, which will contribute to adapting the FATF International Standards for their introduction in Ukraine.

Analysis of recent researches and publications. The relevant areas of contemporary research carried out by Ukrainian scientists are ensuring the country's compliance with the international AML / CFT standards (N. Vnukova, O. Kolodizev, I. Chmutova, 2017 [4]); assessing and managing the risks of ML / TF and applying the risk-based approach (O. Hlushchenko, I. Semehen, 2014 [6]); identifying the directions for institutional changes to ensure the functioning of the risk-based approach (Zh. Andriychenko, 2017 [1]). There also observed an increased attention to theoretical justification of applying a risk-based approach to financial monitoring (N. Vnukova, 2018 [5, 35], S. Yehorycheva, 2018 [9]) as well as its practical implementation in this field (I. Chmutova, Ye. Tkacheva, 2018 [33], A. Chubenko, 2014 [34]).

Highlighting the earlier unsolved parts of the general problem. Along with a significant number of scientific works on the problems of applying a risk-based approach in the field of financial monitoring, attention should be paid to the lack of a holistic conceptual approach to the implementation of a riskbased system for combating money laundering, the financing of terrorism and proliferation of weapons of mass destruction.

The aim of the article is to develop theoretical basis for the formation of a conceptual framework for implementing a risk-based system for combating money laundering, terrorist financing, and the financing of the proliferation of weapons of mass destruction.

The object of the research is the process of combating money laundering, terrorist financing, and the financing of the proliferation of weapons of mass destruction.

The subject is the theoretical bases of the conceptual framework for the formation of a risk-based system for combating money laundering, terrorist financing, and the financing of the proliferation of weapons of mass destruction.

Presentation of basic material of the research. In recent years the State Financial Monitoring Service has achieved certain results in combating the legalization of criminal proceeds and the financing of terrorism [7]. This is primarily due to carrying out the first national risk assessment (NRA) and blocking suspicious financial transactions worth more than USD 1.5 billion, which were confiscated to the Ukrainian budget, etc.

The presence of various approaches and methodologies for assessing and managing risks in the financial monitoring system, revision of the issue of applying a risk-based approach to combating money laundering, the financing of terrorism and proliferation of weapons of mass destruction, carried out assessments of risks of financial monitoring are insufficient in terms of determining the effectiveness of a risk-based approach and applying its principles in the domestic practice, which re- quires developing a conceptual framework for the formation of a risk-based AML / CFT system.

As far back as in 2005, the Cabinet of Ministers of Ukraine (CMU) adopted Order No. 315 "On the Approval of the Concept of Development of the System for Preventing and Countering the Legalization (Laundering) of Proceeds of Crime and Financing of Terrorism for 2005-2010" [27]. This regulatory act stipulates that the development of a AML / CFT system should be carried out in the following dimensions: averting the emergence of prerequisites for the legalization of criminal proceeds and the financing of terrorism; preventing the use of weaknesses of the financial system to legalize criminal proceeds and the financing of terrorism; improving the mechanism for regulating and supervising reporting entities; increasing the effectiveness of law enforcement; creating an effective system for ensuring interaction among the executive authorities involved; raising the qualification level of specialists engaged and the level of their technical support; participating in international cooperation; cultivating among the population the awareness of the need for preventing and countering the legalization of criminal proceeds and the financing of terrorism.

Regulatory support for state mechanisms for ensuring the reporting of the real income of individuals was presented mainly by the adoption by the State Financial Monitoring Service of by-laws aimed at facilitating the execution of provisions of laws and legal acts issued by the highest state authorities as well as at signing memoranda and cooperation agreements with other countries.

Risk-based measures were first mentioned in regulatory documents as early as in 2015, when the Cabinet of Ministers of Ukraine adopted the Ordinance "On the Approval of the Strategy for Development of the System for Prevention and Counteraction to Legalization (Laundering) of Proceeds from Crime, Terrorist Financing and the Financing of Proliferation of Weapons of Mass Destruction for the period till 2020 (hereinafter referred to as the Strategy) [28], aimed at the adaptation of the FATF International Standards. The Strategy envisages measures aimed at averting the emergence of prerequisites for ML / TF; minimizing the risks of using the financial system for ML / TF; increasing effectiveness of activities of law enforcement and other authorized state bodies; developing international cooperation. To implement the provisions of the Strategy, the authors have developed a Conceptual framework for the formation of a risk-based AML / CFT system (hereinafter referred to as the Concept).

The NRA in the field of combating money laundering and terrorist financing (ML / TF) [11] distinguishes a wide range of risks associated with shortcomings of the system of state and primary financial monitoring, including: the imperfection of the system for the initial detection of suspicious financial transactions; the non-modernized (ineffective) system for analyzing information on suspicious financial transactions; the ineffective financial crime investigation system; ineffective sanctions for violations of the law in the field of combating ML / TF; lack of staff and resources for ensuring an effective monitoring in the field of combating ML / TF; lack of sectoral assessment of risks associated with ML / TF; inefficient interaction of law enforcement bodies; improper investigation of cases of ML, tax offenses, terrorist crimes, offenses predicate to ML; disproportionate sentencing. 
All these shortcomings indicate the need to develop a systems approach to applying a risk-based approach in combating ML / TF.

The development and implementation of the Concept would intensify efforts in the field of countering ML / TF, as well as accelerate Ukraine's further integration into the global security space. Under these circumstances, it is extremely important to develop the basis of the Concept, which would define its constituent elements, problems to be solved and the main methods for their solving.

The application of a risk-based approach is aimed at achieving a balance among enhancing the requirements for sources of high risk, reducing the cost of controlling low-risk actors, and improving the practical implementation of international standards, which have been expanded with consideration for new threats, such as financing the proliferation of weapons of mass destruction, and revised in view of transparency and severity of anti-corruption measures.

The strategy for application of a risk-based approach to the formation of a national AML / CFT system in Ukraine involves developing a theoretical, methodological and practical toolkit for implementing the FATF international standards in the field of financial monitoring.

Examining the list of regulations that have a strategic importance for the functioning of the AML / CFT system in Ukraine, three types of documents are singled out: concept, strategy, program. Despite the fact that these strategic documents differ in their essence and purpose, in Ukraine both strategies and programs contain elements inherent in the concepts, in particular, the principles laid down in these documents [15].

Concept (from the Latin conceptio - a comprehending, a system) is considered as a system of thought, a system describing a particular object or phenomenon with regard to its structure, functioning, which contributes to its understanding, interpreting, studying the basic ideas [8].

Strategy (from the Ancient Greek strategia - "I lead the army") is a synthesis of consistent analytical measures, concepts, methods, arguments, and actions designed to find a solution to the problem which can significantly influence the situation and correct it [30].

According to K. Strelnikov, a strategy as a programming document should include an idea, indicate the ultimate goal, ways and methods to achieve it, means and resources that can be spent on its implementation [31]. The difference between a strategy and a concept is that along with the "theory" of development, it reflects the main instruments and methods for achieving the development goals.

In this study concept is considered as a system of views on the problem under consideration, which consists of several interrelated hypotheses and provisions that disclose them.

To develop the Concept of the formation of a risk-based AML / CFT system, a set of hypotheses is defined; the basic principles to be used for its construction are identified; a number of provisions of the concept for the formation of the system are processed using the algorithm proposed by K. Stryzhychenko [32].

The proposed sequence of developing the Concept of the formation of a risk-based AML / CFT system is presented in Figure 1.

Figure 1 demonstrates that the development of the Concept takes place in four stages, which consistently describe the process of its creation.

In order to adapt the FATF International Standards for the purpose of implementing the approaches of the state to the formation of the AML / CFT system, the existing recommendations of international organizations regarding the risk-based AML / CFT system are analyzed (Tbl. 1) [10; 12-14; 20-24].
STAGES OF DEVELOPMENT

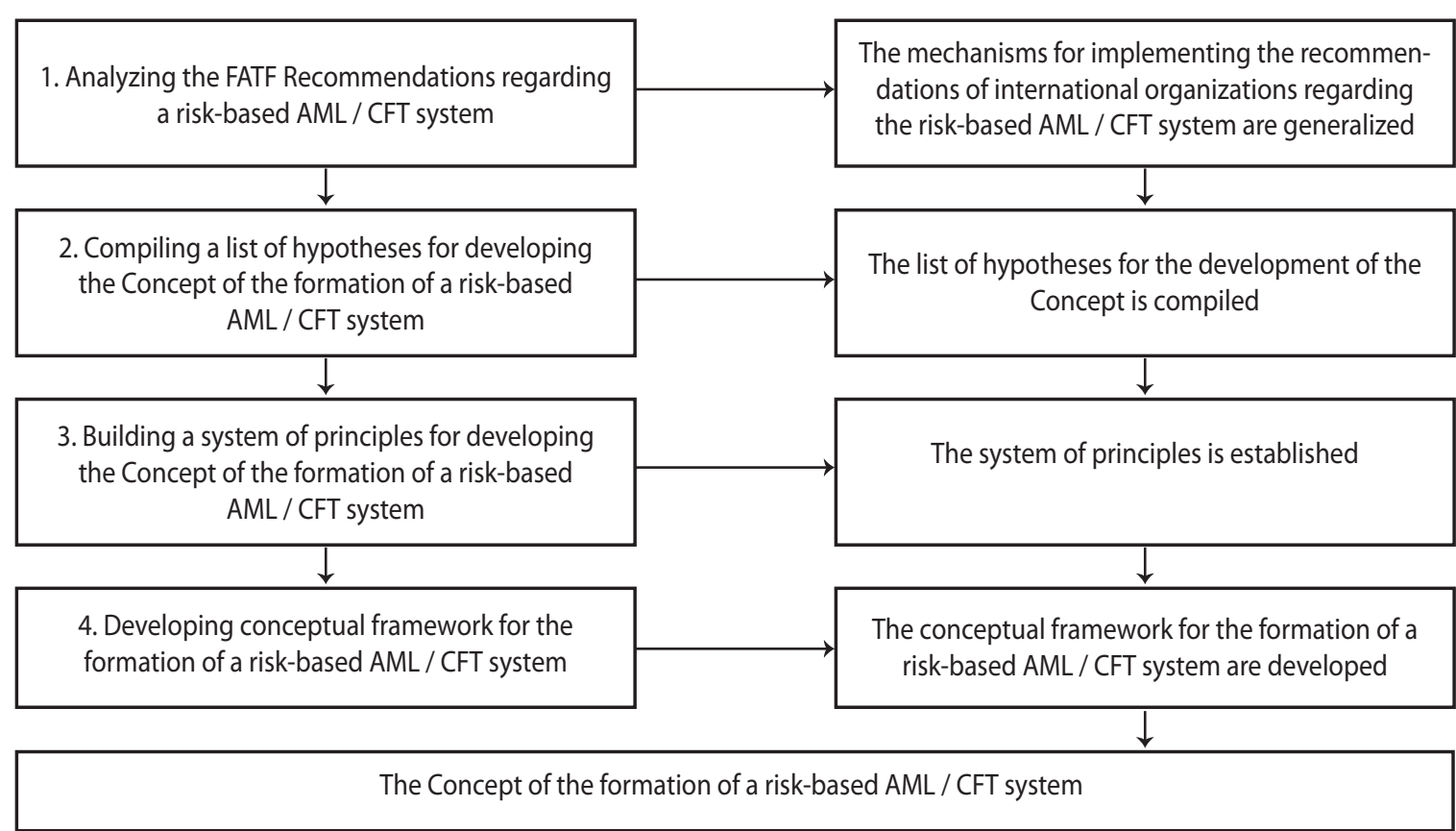

Fig. 1. Sequence of the development of the Concept of the formation of a risk-based AML / CFT system 
Generalization of recommendations of international organizations on a risk-based AML / CFT system

\begin{tabular}{|c|c|c|c|}
\hline Source (document) & Goal & Core principles & Implementation mechanisms \\
\hline 1 & 2 & 3 & 4 \\
\hline $\begin{array}{l}\text { The FATF Guidance } \\
\text { for a Risk-Based Ap- } \\
\text { proach to Prepaid } \\
\text { Cards, Mobile Pay- } \\
\text { ments and Internet- } \\
\text { Based Payment Ser- } \\
\text { vices [14] }\end{array}$ & $\begin{array}{l}\text { Stimulating discussions } \\
\text { on the implementation } \\
\text { of a risk-based approach } \\
\text { to prepaid cards, mobile } \\
\text { payments and internet- } \\
\text { based payment services, } \\
\text { etc. }\end{array}$ & $\begin{array}{l}\text { Mitigation of risks associated with } \\
\text { transactions with virtual currencies, } \\
\text { which provide a powerful new tool } \\
\text { for criminals, terrorist financiers and } \\
\text { other sanctions evaders to move and } \\
\text { store illicit funds, out of the reach of } \\
\text { law enforcement and other authori- } \\
\text { ties }\end{array}$ & $\begin{array}{l}\text { There suggested a conceptual frame- } \\
\text { work for understanding and address- } \\
\text { ing the AML / CFT risks related to one } \\
\text { kind of internet-based payment sys- } \\
\text { tem: virtual currencies }\end{array}$ \\
\hline $\begin{array}{l}\text { Guidance for a Risk- } \\
\text { Based Approach to } \\
\text { Virtual Currencies } \\
{[12 ; 18]}\end{array}$ & $\begin{array}{l}\text { Demonstrating how a } \\
\text { risk-based approach } \\
\text { should be applied within } \\
\text { AML / CFT measures re- } \\
\text { lated to virtual currencies }\end{array}$ & $\begin{array}{l}\text { The focus is on centers which are } \\
\text { points of intersection that provide } \\
\text { gateways to the regulated financial } \\
\text { system, in particular, convertible vir- } \\
\text { tual currency exchangers }\end{array}$ & $\begin{array}{l}\text { Applying the risk-based approach } \\
\text { to the ML / TF risks associated with } \\
\text { VCPPS, and not on other types of VC fi- } \\
\text { nancial products, such as VC securities } \\
\text { or futures products }\end{array}$ \\
\hline $\begin{array}{l}\text { Risk-Based Approach } \\
\text { Guidance for the } \\
\text { Banking Sector [13] }\end{array}$ & $\begin{array}{l}\text { Assisting countries, com- } \\
\text { petent authorities and } \\
\text { banks in the design and } \\
\text { implementation of a risk- } \\
\text { based approach to AML / } \\
\text { CFT by providing general } \\
\text { guidelines and examples } \\
\text { of current practice }\end{array}$ & $\begin{array}{l}\text { Where the ML / TF risks are higher, } \\
\text { banks should always apply enhanced } \\
\text { due diligence, although national law } \\
\text { or regulation might not prescribe ex- } \\
\text { actly how these higher risks are to be } \\
\text { mitigated (e.g., varying the degree of } \\
\text { enhanced ongoing monitoring) }\end{array}$ & $\begin{array}{l}\text { Assessing risks to help banks under- } \\
\text { stand how and to what extent the ML } \\
\text { /TF threats identified will affect them. } \\
\text { Developing a classification meant to } \\
\text { determine the volume of resources } \\
\text { required to mitigate risks }\end{array}$ \\
\hline $\begin{array}{l}\text { Emerging Terrorist Fi- } \\
\text { nancing Risks [10] }\end{array}$ & $\begin{array}{l}\text { Assisting jurisdictions } \\
\text { and the private sector to } \\
\text { implement robust CFT } \\
\text { systems which take into } \\
\text { account changing TF risks, } \\
\text { trends and methods }\end{array}$ & $\begin{array}{l}\text { Consideration and analysis of some } \\
\text { of the emerging risks identified by } \\
\text { members of the FATF global network }\end{array}$ & $\begin{array}{l}\text { Determining the mechanism of the } \\
\text { functioning of various terrorist organi- } \\
\text { zations that receive, use, and manage } \\
\text { funds in order to reveal, suppress, and } \\
\text { punish terrorist activity and TF }\end{array}$ \\
\hline $\begin{array}{l}\text { Risk-Based Approach } \\
\text { Guidance for Money } \\
\text { Service Businesses } \\
\text { [22] }\end{array}$ & \multirow{3}{*}{$\begin{array}{l}\text { Supporting the devel- } \\
\text { opment of a common } \\
\text { understanding of what } \\
\text { the risk-based approach } \\
\text { involves. Outlining the } \\
\text { high-level principles } \\
\text { involved in applying the } \\
\text { risk-based approach. } \\
\text { Indicating good practice } \\
\text { in the design and imple- } \\
\text { mentation of an effective } \\
\text { risk-based approach }\end{array}$} & $\begin{array}{l}\text { Adopting a risk-based approach im- } \\
\text { plies the adoption of a risk manage- } \\
\text { ment process for dealing with money } \\
\text { laundering and terrorist financing. } \\
\text { This process encompasses recogniz- } \\
\text { ing the existence of the risk(s), un- } \\
\text { dertaking an assessment of the risk(s) } \\
\text { and developing strategies to manage } \\
\text { and mitigate the identified risks }\end{array}$ & $\begin{array}{l}\text { A risk analysis must be performed, } \\
\text { and kept up to date, to determine } \\
\text { where the ML / TF risks are the great- } \\
\text { est. Money service businesses (MSBs) } \\
\text { will need to identify higher risk cus- } \\
\text { tomers, products and services, includ- } \\
\text { ing delivery channels, and geographi- } \\
\text { cal locations }\end{array}$ \\
\hline $\begin{array}{l}\text { FATF Guidance on the } \\
\text { Risk-Based Approach } \\
\text { for Real Estate Agents } \\
\text { [23] }\end{array}$ & & \multirow{2}{*}{$\begin{array}{l}\text { Understanding and responding to the } \\
\text { threats and vulnerabilities: a national } \\
\text { risk assessment (NRA); a legal/ regu- } \\
\text { latory framework that supports the } \\
\text { application of a risk-based approach; } \\
\text { designing a supervisory framework } \\
\text { to support the application of the risk- } \\
\text { based approach; identifying the main } \\
\text { actors and ensuring consistency; } \\
\text { Information exchange between the } \\
\text { public and private sector }\end{array}$} & $\begin{array}{l}\text { A good understanding by brokers of } \\
\text { the risks and their ability to exercise } \\
\text { sound judgment. A continuous build- } \\
\text { ing of expertise within MSBs, including } \\
\text { for example, through training, engag- } \\
\text { ing experts and taking professional } \\
\text { advice, and "learning by doing". The } \\
\text { process will always benefit from infor- } \\
\text { mation sharing by competent authori- } \\
\text { ties and self-regulatory organizations } \\
\text { (SROs) }\end{array}$ \\
\hline $\begin{array}{l}\text { FATF Guidance on the } \\
\text { Risk-Based Approach } \\
\text { for Dealers in Precious } \\
\text { Metals and Stones } \\
\text { [24] }\end{array}$ & & & $\begin{array}{l}\text { Identifying and verifying customers/ } \\
\text { counterparties before establishing a } \\
\text { business relationship, e.g., assuming } \\
\text { contractual obligations. Identifying } \\
\text { beneficial owners and taking neces- } \\
\text { sary measures to verify their identity. }\end{array}$ \\
\hline
\end{tabular}


Table 1 (continued)

\begin{tabular}{|c|c|c|c|}
\hline 1 & 2 & 3 & 4 \\
\hline & & & $\begin{array}{l}\text { Obtaining information about the } \\
\text { sphere of activity of a customer / coun- } \\
\text { terparty, including the expected type } \\
\text { and level of the proposed operations }\end{array}$ \\
\hline $\begin{array}{l}\text { Money Laundering } \\
\text { \& Terrorist Financing } \\
\text { Risk Assessment Strat- } \\
\text { egies (FATF) [21] }\end{array}$ & $\begin{array}{l}\text { Providing information } \\
\text { on the development of a } \\
\text { national AML / CFT risk as- } \\
\text { sessment system }\end{array}$ & $\begin{array}{l}\text { Usefulness of conducting a risk as- } \\
\text { sessment to policymakers in identify- } \\
\text { ing AML / CFT priorities. Assessments } \\
\text { should be tied to strategic planning } \\
\text { and linked to specific actions }\end{array}$ & $\begin{array}{l}\text { Identifying high-risk customers and } \\
\text { high-risk transactions. Coordination on } \\
\text { national AML / CFT strategy }\end{array}$ \\
\hline $\begin{array}{l}\text { Money Laundering } \\
\text { \& Terrorist Financ- } \\
\text { ing Vulnerabilities of } \\
\text { Commercial Websites } \\
\text { and Internet Payment } \\
\text { Systems (FATF) [20] }\end{array}$ & $\begin{array}{l}\text { Increasing public and pri- } \\
\text { vate sector understanding } \\
\text { of ML / TF risks associated } \\
\text { with commercial websites } \\
\text { and Internet payment } \\
\text { systems and to raise } \\
\text { global awareness of the } \\
\text { methods for ML / TF using } \\
\text { these conduits }\end{array}$ & $\begin{array}{l}\text { There highlighted various vulner- } \\
\text { abilities of commercial websites and } \\
\text { Internet payment systems: non face- } \\
\text { to-face registration, which can cause } \\
\text { different problems with identity veri- } \\
\text { fication; speed of transactions; limited } \\
\text { human intervention and high number } \\
\text { of transactions, which can cause dif- } \\
\text { ficulties with auditing, monitoring } \\
\text { and detecting suspicious financial } \\
\text { transactions, etc. }\end{array}$ & $\begin{array}{l}\text { Implementing important worldwide } \\
\text { security teams patrolling sites to de- } \\
\text { tect fraud and misuse. } \\
\text { Applying risk-based Customer Due Dil- } \\
\text { igence (simplified CDD vs. enhanced } \\
\text { CDD). } \\
\text { Scoring customer risk at opening of } \\
\text { account. } \\
\text { Risk-based verification of information } \\
\text { entered by customers. } \\
\text { Automated call, random charges to } \\
\text { verify identities of customers }\end{array}$ \\
\hline
\end{tabular}

As can be seen from Table 1, international organizations, in particular, FATF, generalized and developed recommendations for adopting a risk-based approach when using payment cards, mobile payments, and Internet-based payment services, in particular, through commercial websites and Internet payment systems; carrying out transactions with virtual assets; in the work of banks; countering the financing of terrorism; providing monetary services; in real estate transactions, etc.

Procedures concerning anti-money laundering and / or countering the financing of terrorism applied by the private sector and competent authorities can provide relevant information and instructions on which to base a national assessment of the money laundering and / or terrorist financing risks. The report on combating the financing of terrorism, which is submitted by financial institutions and other specified non-financial institutions, draws attention to the fact that when developing international standards for countering ML / TF they took steps to study their customers and kept corresponding records [5]. The importance of financial information in counter-terrorism investigations has grown significantly in recent years [24].

To ensure the functioning of the implementation mechanisms, it is proposed to create a conceptual framework for countering ML / TF, which implies coordinating the approved national strategy through the determination of possible ways for achieving the planned results.

The research carried out made it possible to formulate the following findings:

Finding 1 . In the process of studying the existing regulations that have a strategic importance for the functioning of the national AML / CFT system in Ukraine, it is established that the country has no concept that would provide for a comprehensive solution to the issue of the formation of a national risk-based AML / CFT system.
Based on the data in Table 1, it can be concluded that the variety of target indicators and goals specified in the strategic documents causes certain problems.

First, the impossibility of defining such target indicators that would simultaneously meet the requirements of the most important strategic goals and acquire a specific form of manifestation (i.e., could be measured), which would allow for an objective assessment of achieving an individual target indicator.

Secondly, there is a discrepancy between the development goals and objectives, on the one hand, and the ways of their realization, on the other. Further incorrect assessment of the level of implementation of the strategies reinforces incorrect signals and only postpones the achievement of the goals, i.e., reduces the likelihood of achieving goals and target indicators.

Thirdly, there arises a problem of abstract nature (nonspecificity) of goals and objectives (setting permanent common objectives that are not directly related to specific problem situations) [8].

In addition to the problems revealed, there identified the most common shortcomings of the strategic documents presented in Table 1, which can slow down creating the Concept of the formation of a risk-based AML / CFT system: lack of interconnection between various strategies for the development of the relevant elements comprising the national AML / CFT system in Ukraine; insufficient consideration of the existing world experience and the lack of pro-active measures to take commitments for its application in the financial monitoring system. Non-compliance of the goals and objectives of domestic strategic documents regarding the AML / CFT system with those theoretically justified and recommended by international organizations; continuous predominance of tactical objectives as opposed to measures aimed at solving strategic tasks and problems of the AML / CFT system. In the vast majority of cases the priority is given to the implementation of certain policy 
objectives. Specific measures aimed at ensuring the development of the AML / CFT system are the result of the need to quickly solve new problems and the setting of goals that can be achieved but in practice will not contribute to the development of the AML / CFT system.

The issue of integrated development of the AML / CFT system is not a priority. Neither state authorities nor associations of professional participants in financial markets, which are reporting entities, have proposed to discuss a strategically important document that would focus on this issue. Yet the CMU adopted Ordinance No. 601-r of August 30, 2017 "On the Implementation of the Strategy for Development of the System for Prevention and Counteraction to Legalization (Laundering) of Proceeds from Crime, Terrorist Financing and the Financing of Proliferation of Weapons of Mass Destruction for the period till 2020"[26]. The issued document envisages measures aimed at preventing and / or mitigating negative consequences of risks related to the AML / CFT system, which include: non-transparent funding of political parties; inadequate identification and authorization of suspicious financial transactions carried out by national public figures; ineffective measures to identify the ultimate beneficial owners (controllers) and set control over them; improper identification and inadequate mitigating of factors contributing to an increase in the share of shadow economy and offshore operations in the financial system; low level of trust in the financial system; high cash flow; outflow of financial capital from the country, etc.

All the identified risks are macroeconomic ones, therefore, they require developing a conceptual framework for the formation of the AML / CFT system.

The methodological basis for the Concept of a risk-based AML / CFT system is the systems, institutional, and functional approach. The study [16] indicates that the application of the systems approach to a risk-based AML / CFT system ensures: integrity of the formation of an AML / CFT system; systematization of the transfer and receipt of information by subjects within the system, throughout the hierarchy of interrelations, as well as its external use by other reporting entities.

The institutional approach [16] is aimed at forming an effective institutional structure of the risk-based AML / CFT system by including legislative, regulatory, law enforcement bodies, which will reduce the information asymmetry in the system and allow for the formation of effective internal and external institutional mechanisms based on exchange and distribution of information flows among them.

The functional approach allows considering the riskbased AML / CFT system over time, i.e., in terms of its performance.

An element of the methodological basis for the development of the Concept is hypotheses that take into account characteristics of the reform of state regulation of financial markets and their integration into the European Economic Space (EES).

A hypothesis is a suggestion of a possible solution to a problem which is to be verified empirically [15]. In the scientific literature there are a number of rules of hypothesizing (Fig. 2).

As can be seen from Figure 2, five rules are singled out: universality - from a number of opposing hypotheses put forward to interpret a series of facts, the one that more universally explains the majority of them is preferable. Since each hypothesis requires proof, then, proving a uniform hypothesis provides the possibility of explaining more factors; minority - to explain series of related facts, fewer hypotheses should be put forward, and their connection should be as close as possible. This rule

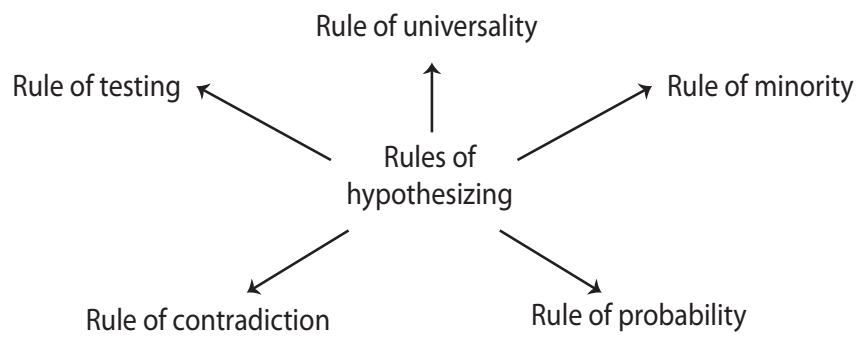

Fig. 2. Rules of hypothesizing

correlates with the rule of universality, i.e., considering the totality of hypotheses as a system, it is necessary to achieve a close linkage among the elements of this system but not to expand the system of hypotheses by increasing their number; probability - when suggesting a hypothesis, it is necessary to be aware of the nature of probability of conclusions of hypothesis testing. The nature of probability of conclusions is characterized by two aspects: first, most of the environmental conditions in which management decisions are made and hypotheses are tested are stochastic in nature; second, the external environment is a dynamic formation, therefore, hypotheses that were clearly formulated and proved under certain conditions can be irrelevant under new conditions of the functioning of economic systems; contradiction - it is impossible to be guided by contradictory hypotheses. If there are two hypotheses that con- tradict each other, then one of them is irrelevant or incorrectly proved; testing - a hypothesis is to be verified in the course of a study. Any hypothesis that cannot be tested is at the stage of speculation [15].

Finding 2. Studying theoretical works on combating ML / TF has allowed to put forward and prove the following hypotheses:

The process of assessing the risks of money laundering and / or terrorist financing should give an idea whether the existing legislation is adequate for emerging threats and whether the current methods of control and enforcement of the law are equivalent. Where the law is inadequate, there is vulnerability. Where the law is equivalent, but control and verification are weak, law enforcement will prevail. Where law enforcement is weak, law has a small preventive effect [3]. 
The application of the risk assessment methodology through using a combination of approaches (retrospective and prospective ones) with regard to the conditions of certainty and uncertainty. Retrospective risk assessments have the advantage of drawing on data from past events to help anticipate future problems.

An assessment of risks related to the AML / CFT system should be carried out based on assessing changes in quantitative and qualitative indicators over time. The determination of the level of risks should be carried out based on a wide range of indicators, including both quantitative and qualitative ones, which contributes to a more objective assessment. In case when little or no data is available, the process of risk assessment involves using whatever information is known to anticipate real or potential consequences. This hypothesis rests rather upon qualitative than quantitative indicators.

A national ML / TF risk assessment should be considered as "fundamental background information" to assist supervisors, law enforcement bodies, the financial intelligence unit, and financial institutions. This hypothesis requires that competent authorities periodically review their awareness of current ML / TF methods and reassess the effectiveness of the established safeguards.

The integration of the AML / CFT system into the global and European Economic Space requires strengthening protection against external influences on it. The hypothesis stems from the fact that Ukraine's accession to the WTO, the signing of the Association Agreement between Ukraine and the EU, and the opening of relevant markets lead to possible emergence of systemic risks, and, therefore, increase in the level of financial risks. This problem requires a comprehensive solution at the relevant institutional levels.

There is a need to change the model for regulation of the AML / CFT system in the context of integration of the country into the EES. The intensification of discussions on the transition to a different model of regulation of the AML / CFT system was due to the negative impact of the financial and economic crisis of 2008, which indicated the failure of government regulatory bodies to mitigate the manifestation of systemic crises in financial markets.

The intensification of the transition of the EU countries from one regulatory model to another, which started in 2009, along with an increase in protection of the rights of consumers of financial services, convincingly confirms the need to evaluate the existing regulatory models in EU countries with the possibility of implementing their practices in Ukraine.

A large number of jurisdictions, independently or in collaboration, have begun studies on global illicit cash flows (which often contain information about cash smuggling). For jurisdictions where such cases are observed (and for which such studies are sufficiently developed), the studies can be used to display incoming and outgoing flows (countries of origin / countries of destination) of funds from criminal activity.

Similar to requests for assistance, information on illicit cash flows can contribute to corresponding improvements in a jurisdiction in a particular year. The studies and information should be restricted, if not secret.

Elements of the risk-based AML / CFT system interact with each other. The hypothesis involves the establishment of links and evaluation of the interaction among institutional participants in the AML / CFT system in accordance with their place in the institutional structure which is confirmed by the function they perform in the system and their economic ties.

The level of state regulation affects the development of the risk-based AML / CFT system. Despite the fact that most scientists fully agree with this statement, there is an ambiguity of practical evidence (confirmation or refutation). Such complexity is associated with the lack of a reliable information base and consistency of indicators, which can serve as the basis for proving the hypothesis.

Testing the hypotheses (1-8) for contradiction (the rule of contradiction, Fig. 2) made it possible to conclude that they do not negate each other and are not mutually exclusive. Based on the analysis of works on the methodology of scientific cognition, the methods for proving the hypotheses are substantiated, as indicated in Table 2 .

Table 2

Methods of scientific cognition and the state of proving the hypotheses of the Concept of the formation of a risk-based AML / CFT system

\begin{tabular}{|l|l|c|}
\hline \multicolumn{1}{|c|}{ Hypothesis } & \multicolumn{1}{|c|}{ Methods of scientific cognition } & \multicolumn{1}{|c|}{$\begin{array}{c}\text { State (proved / } \\
\text { disproved) }\end{array}$} \\
\hline \multicolumn{1}{|c|}{$\mathbf{1}$} & \multicolumn{1}{c|}{$\mathbf{2}$} & $\mathbf{3}$ \\
\hline $\begin{array}{l}\text { 1. The process of assessing the risks of money laundering and / or ter- } \\
\text { rorist financing should give an idea whether the existing legislation is } \\
\text { adequate for emerging threats and whether the current methods of } \\
\text { control and enforcement of the law are equivalent }\end{array}$ & $\begin{array}{l}\text { Analysis and synthesis, induction and } \\
\text { deduction, method of comparison, mono- } \\
\text { graphic one }\end{array}$ & Proved \\
\hline $\begin{array}{l}\text { 2. The application of the risk assessment methodology through using a a } \\
\text { combination of approaches (retrospective and prospective ones) with } \\
\text { regard to the conditions of certainty and uncertainty }\end{array}$ & $\begin{array}{l}\text { Historical and logical method, analysis and } \\
\text { synthesis, induction and deduction, meth- } \\
\text { od of comparison, method of abstraction }\end{array}$ & Proved \\
\hline $\begin{array}{l}\text { 3. An assessment of risks related to the AML / CFT system should be } \\
\text { carried out based on assessing changes in quantitative and qualitative } \\
\text { indicators over time }\end{array}$ & $\begin{array}{l}\text { Analysis and synthesis, induction and de- } \\
\text { duction, method of comparison }\end{array}$ & Proved \\
\hline $\begin{array}{l}\text { 4. A national ML /TF risk assessment should be considered as "funda- } \\
\text { mental background information" to assist supervisors, law enforce- } \\
\text { ment bodies, the financial intelligence unit, and financial institutions }\end{array}$ & $\begin{array}{l}\text { Analysis and synthesis, induction and de- } \\
\text { duction, method of comparison, method } \\
\text { of abstraction, historical and logical one }\end{array}$ & Proved \\
\hline
\end{tabular}


Table 2 (continued)

\begin{tabular}{|l|l|l|}
\hline \multicolumn{1}{|c|}{1} & \multicolumn{1}{|c|}{$\mathbf{2}$} & $\mathbf{3}$ \\
\hline $\begin{array}{l}\text { 5. The integration of the AML / CFT system into the global and Europe- } \\
\text { an Economic Space requires strengthening protection against external } \\
\text { influences on it }\end{array}$ & $\begin{array}{l}\text { Analysis and synthesis, induction and de- } \\
\text { duction, method of comparison }\end{array}$ & Proved \\
\hline $\begin{array}{l}\text { 6. Information on illicit cash flows can contribute to corresponding } \\
\text { improvements in a jurisdiction in a particular year. The studies and in- } \\
\text { formation should be restricted, if not secret }\end{array}$ & $\begin{array}{l}\text { Analysis and synthesis, induction and de- } \\
\text { duction, method of comparison, method } \\
\text { of abstraction }\end{array}$ & Proved \\
\hline $\begin{array}{l}\text { 7. Elements of the risk-based AML / CFT system interact with each } \\
\text { other }\end{array}$ & $\begin{array}{l}\text { Analysis and synthesis, induction and de- } \\
\text { duction, method of comparison, method } \\
\text { of abstraction }\end{array}$ & Proved \\
\hline $\begin{array}{l}\text { 8. The level of state regulation affects the formation of the risk-based } \\
\text { AML / CFT system }\end{array}$ & $\begin{array}{l}\text { Analysis and synthesis, induction and de- } \\
\text { duction, method of comparison, method } \\
\text { of abstraction, historical and logical } \\
\text { one, analytic hierarchy process (AHP) }\end{array}$ & Proved \\
\hline
\end{tabular}

As seen from Table 2, all the hypotheses are proved.

Finding 3. On the way to implementing the Concept, the leading role is played by principles that will underlie the implementation of each element of the developed Concept. A principle is a theoretical provision that does not require proof.

Different theories and branches of science are characterized by their own principles, which may be fundamental or specific to certain sciences. The Concept of the formation of a risk-based AML / CFT system rests upon the following key principles, defined based on the analysis of work [15]:

1. Functionality - concerning each element of the riskbased AML / CFT system, a special system and technological proce2. ss for countering ML / TF is carried out.

2. Transparency - the maximum openness of the AML / CFT system to external users through providing access of consumers to basic information as well as analytical and statistical information about its operation.

3. Uniformity - is characterized by the presence of a unified legal/ regulatory framework, a unified methodology for the formation of financial and statistical reporting of all professional participants in the AML / CFT system.

4. Sustainability - the risk-based AML / CFT system is capable of counteracting external shocks and internal threats and eliminating the latter with the active participation of regulatory and supervisory authorities.

5. Efficiency of activities of participants in the system each market participant maintains such behavior that ensures them maximizing profits while minimizing their risks.

6. Trust - participants in the system are able to predict the behavior of other participants, forming more or less stable expectations regarding the situation.

7. Social responsibility - a responsible attitude of participants in the system to their services, employees, consumers, owners; active social position, which is realized through coexistence, interaction, and maintaining an ongoing dialogue with representatives of business and society, government, stakeholders to effectively solve acute economic, social, humanitarian, and environmental problems.
The proof of the hypotheses put forward and the definition of the basic principles made it possible to form the Concept with regard to specific features of the hypotheses. The Concept for the development of a risk-based AML / CFT system is based on the following provisions:

Provision 1 . The supreme supervisory authority of the AML / CFT system (the State Financial Monitoring Service) should have a regulatory character [25] in order to ensure maximum institutional and personal independence. Thus, the State Financial Monitoring Service is the central executive body, whose activities are directed and coordinated by the Cabinet of Ministers of Ukraine through the Minister of Finance and implementing the national AML / CFT policy.

The activity of the State Financial Monitoring Service is guided by the Constitution and laws of Ukraine, decrees of the President of Ukraine, and resolutions of the Verkhovna Rada of Ukraine adopted in accordance with the Constitution of Ukraine and laws of Ukraine, acts of the Cabinet of Ministers of Ukraine, and other legislative acts.

Institutional and personal independence in exercising control can be implemented with certain restrictions.

Provision 2. Excessive consolidation and centralization of competencies aimed at combating ML / TF will violate the institutional isomorphism, therefore, the main tasks of the State Financial Monitoring Service are [25]: ensuring the functioning and development of a unified information system in the field of preventing and counteracting the legalization (laundering) of criminal proceeds, the financing of terrorism and proliferation of weapons of mass destruction; establishing cooperation, interaction, and information exchange with government agencies, the National Bank, competent authorities of foreign states, and international organizations in the field of preventing and countering the legalization (laundering) of criminal proceeds, the financing of terrorism and proliferation of weapons of mass destruction.

The provision on the State Financial Monitoring Service is based on the following considerations [25]: centralization of powers to ensure combating ML / TF is possible only when the regulatory model is changed to a risk-based one, which is currently a promising goal, but its achievement requires significant changes in the executive power system, in particular, concerning economic regulation and law enforcement; concentration 
of powers related to combating ML / TF in terms of redistribution of investigation functions will mean a transition from the administrative to the police or prosecution and judicial model of organization of the financial monitoring system; excessive concentration of powers of the State Financial Monitoring Service will cause an institutional imbalance, strengthen the effect of failure to act or avoidance of responsibility for actions by financial regulators; transformation of the organizational AML / CFT system into a risk-based one in combination with the organizational transformation of the entire AML / CFT system should take place.

Provision 3. To implement control, in particular, over AML / CFT, it is necessary to previously specify norms and signs of their violation, as well as provide access to relevant information.

It is necessary to fundamentally decide on the direction of reforming the AML / CFT system - further division by sector or subject, or by function of the state financial policy.

Based on this, it is possible to define the subject-object domain of the implementation of control functions by each AML / CFT system.

Provision 4. The institutional capacity and effectiveness of the AML / CFT system objectively requires improving personnel, financial, informational, and methodological support.

Provision 5. The risk-based AML / CFT system must meet the requirements of the EES. The provision is formed with regard to the European vector of development chosen by Ukraine, which involves the brining of its legislation in compliance with EU standards, including those that concern combating ML / TF.

Provision 6. A prerequisite for a successful functioning of the AML / CFT system is enhancing institutional regulation and self-regulation in the domestic practice, and limiting state regulation.

This is facilitated by the implementation of the Strategy for Development of the System for Prevention and Counteraction to Legalization (Laundering) of Proceeds from Crime, Terrorist Financing and the Financing of Proliferation of Weapons of Mass Destruction for the period till 2020 (hereinafter referred to as the Strategy) [28].

Provision 7. The AML / CFT system is influenced by systemic risks due to the globalization of financial relations, which requires improving state regulation of the system by changing the regulatory model.

The complex of the proposed eight hypotheses and seven provisions of the Concept (Fig. 3), based on the established interrelations between them, will contribute to the formation of the national AML / CFT system in Ukraine in the context of changing its institutional structure.

The conceptual framework for the current development of the risk-based AML / CFT system with consideration for these provisions is reflected in Figure 4.

The priority areas for the functioning and development of the national risk-based AML / CFT system in Ukraine, except reducing relevant risks, will be as follows [28;3]: securing the status of Ukraine as a reliable partner of the international community in the field of preventing and combating ML / TF; averting the emergence of prerequisites for ML / TF; improving legislation in the field of AML / CFT; enhancing activities of competent authorities in the field of preventing and combating
ML / TF; improving the mechanism for regulating and supervising activities of reporting entities; ensuring the development of specialists; organizing effective international cooperation; providing the public with information on measures taken to prevent and combat ML / TF; reducing the information asymmetry for participants in the national AML / CFT system in Ukraine.

The final result of the development of the risk-based AML / CFT system for the medium term will be its qualitative transformation. The implementation of the Concept will contribute to the development of Ukraine as a democratic, legal state as well as protection of its national interests, improvement of socio-economic relations and formation of the foundations of a civil society.

It will provide a possibility for ensuring: systematic implementation of the state policy in the field of combating ML / TF; compliance of the national AML / CFT system with international legal standards; effective cooperation and constant information exchange with the executive authorities, other state bodies - reporting entities, as well as competent authorities of foreign states and international organizations in this area; compliance with and unfailing implementation of the complex of legal requirements for activities of the specified reporting entities; timely submission to authorized law enforcement bodies as well as intelligence units of Ukraine of relevant summary materials indicating suspicions of ML / TF; improvement of quality of retraining and advanced training of specialists of state authorities engaged in financial monitoring and employees of reporting entities; stimulation of investment in the national economy from economically developed countries; ability of the financial system of Ukraine to counter the threats of money laundering and possible cases of using it to finance terrorism; provision of assistance in pumping up the state budget.

Conclusions. Thus, the developed Concept for the formation of a risk-based AML / CFT system rests upon a new scientific approach to searching ways to improve the functioning and development of the AML / CFT system, the implementation of the proposed conceptual framework of which will allow achieving the expected results. This will strengthen the AML / CFT system, make it more resilient to systemic crises, and create a stable ground for its long-term development.

\section{LITERATURE}

1. Андрійченко Ж. О. Визначення напрямів інституційних змін для забезпечення ефективного функціонування ризикорієнтованого підходу у сфері фінансового моніторингу. Глобальні та національні проблеми економіки. 2017. Вип. 17. URL: http://globalnational.in.ua/issue-17-2017

2. Андрійченко Ж. О., Літвінова С. О. Статистичне обгрунтування необхідності запровадження ризик-орієнтованого підходу у сфері фінансового моніторингу в Україні. Проблеми і перспективи розвитку підприємниитва. 2017. № 2 (17). С. 49-55.

3. Бачо Р. Й. Формування концепції розвитку ринків небанківських фінансових послуг України. Глобальні та національні проблеми економіки. 2016. № 13. URL: http://globalnational.in.ua/archive/13-2016/132.pdf

4. Внукова Н. М., Колодізєв О. М., Чмутова І. М. Аналіз міжнародного досвіду застосування ризик-орієнтованого підходу у сфері протидії відмиванню коштів, фінансуванню теро- 


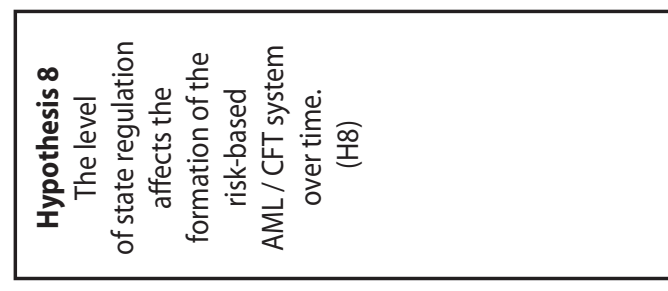

\begin{tabular}{|c|}
\hline 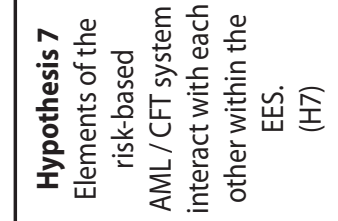 \\
\hline
\end{tabular}

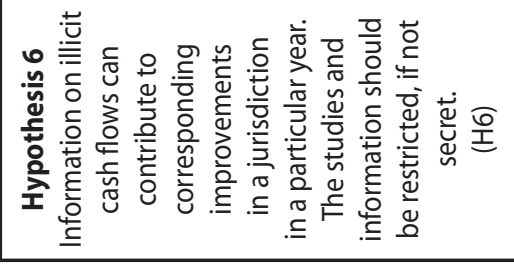

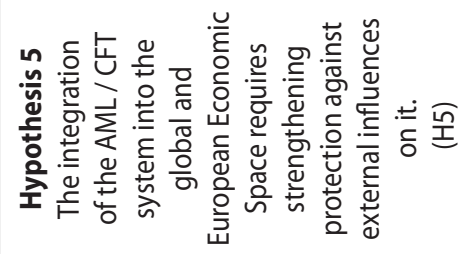

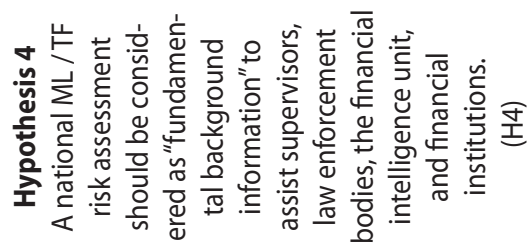

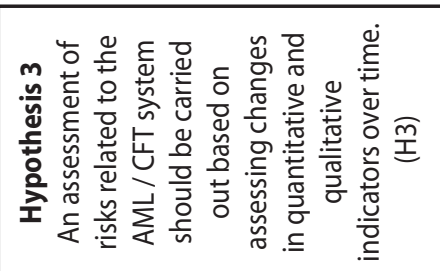

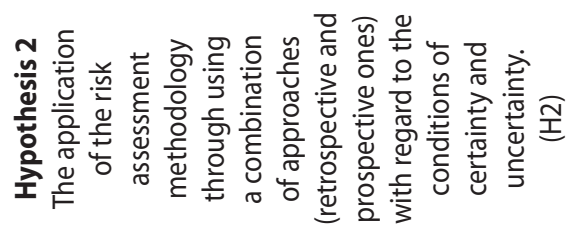

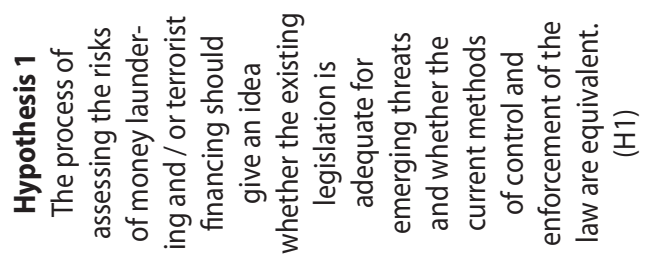
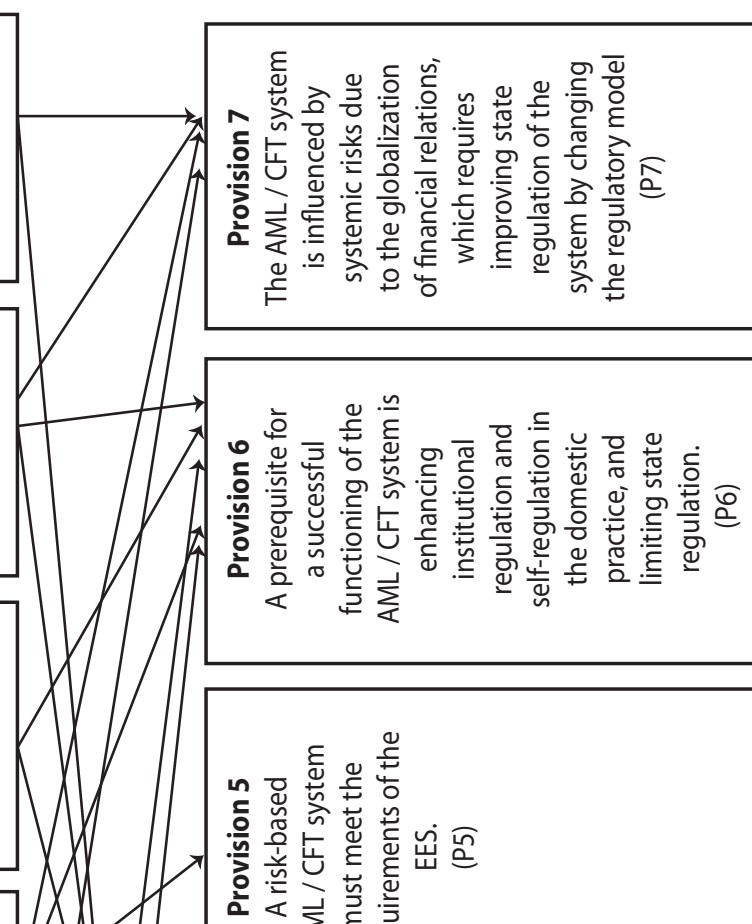

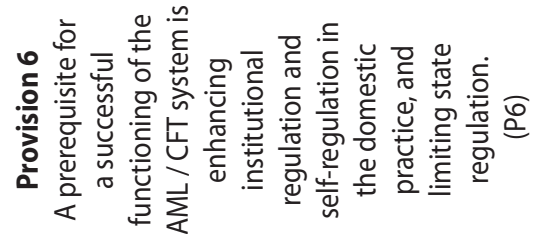

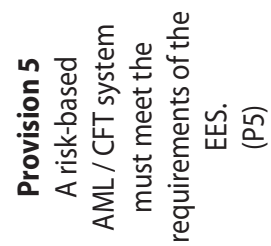

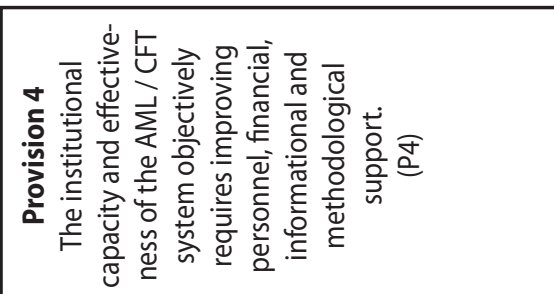

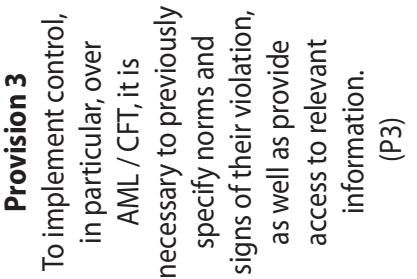

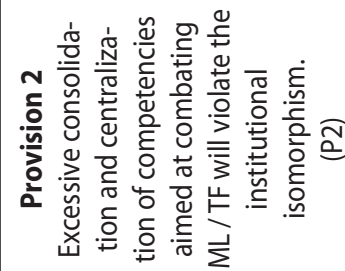

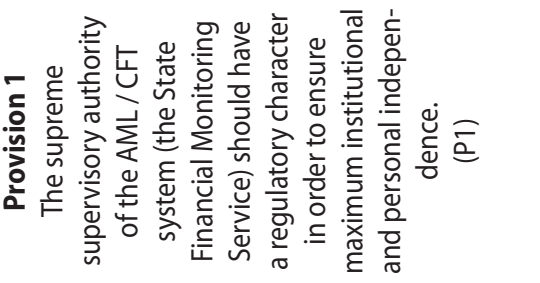



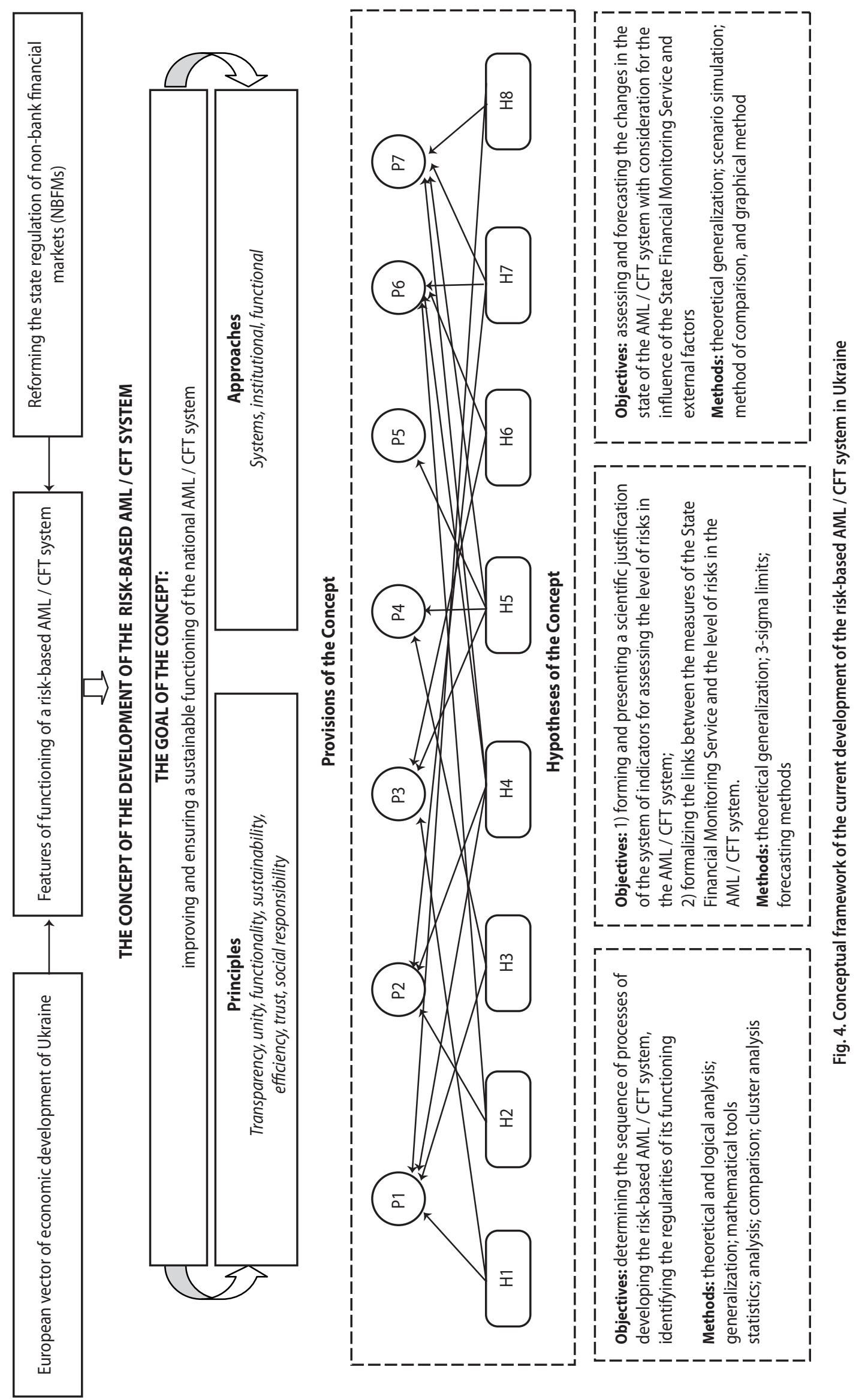
ризму та розповсюдження зброї масового знищення. Глобальні та національні проблеми економіки. 2017. Вип. 17. URL: http:// globalnational.in.ua/issue-17-2017

5. Внукова Н. М. Ризик-орієнтований підхід суб'єктів первинного фінансового моніторингу до класифікації клієнтів // Сучасні проблеми фінансового моніторингу : зб. матеріалів VI Всеукр. наук.-практ. конф. Харків : ХНЕУ ім. С. Кузнеця ; Ексклюзив, 2018. С. 20-24.

6. Глущенко О. О., Семеген І. Б. Антилегалізаційний фінансовий моніторинг: ризик-орієнтований підхід : монографія. Київ : УБС НБУ, 2014. 386 с.

7. Голова Державної служби фінансового моніторингу України надав інтерв'ю Національному інформаційному агентству України «УКPIHФОРМ». URL: http://sdfm.gov.ua/news. php?news_id=3490\&lang=uk

8. Данилов Ю. А., Абрамов А. Е., Буклемишев О. В. Реформа финансовых рынков и небанковсого финансового сектора. М. : РАНХиГС, 2017. 106 с.

9. Єгоричева С. Б. Впровадження ризик-орієнтованого нагляду у системі фінансового моніторингу в Україні // Сучасні проблеми фінансового моніторингу : зб. матеріалів VI Всеукр. наук.-практ. конф. (м. Харків, 23 листоп. 2018 р.). Харків : ХНЕУ ім. С. Кузнеця ; Ексклюзив, 2018. С. 5-8.

10. Звіт FATF «Ризики фінансування тероризму». URL: http://www.sdfm.gov.ua/content/file/Site_docs/2016/20160727/ Zmist1.pdf

11. Звіт про проведення національної оцінки ризиків у сфері запобігання та протидії легалізації (відмиванню) доходів, одержаних злочинним шляхом, та фінансуванню тероризму. URL: http://www.sdfm.gov.ua/content/file/Site_ docs/2016/20161125/zvit_ukr.pdf

12. Керівництво по застосуванню ризик-орієнтованого підходу «Віртуальні валюти». URL: http://www.sdfm.gov.ua/content/file/Site_docs/2016/20160805/rek\%202.pdf

13. Керівництво ФАТФ щодо використання ризикорієнтованого підходу для банківського сектора. URL: http:// www.sdfm.gov.ua/content/file/Site_docs/2016/20160805/ rek\%201.pdf

14. Керівництво ФАТФ щодо застосування ризикорієнтованого підходу до передплачених карток, мобільних платежів і послуг онлайн-платежів. URL: http://www.fatf-gafi. org/publications/fatfrecommendations/documents/rba-npps2013.html

15. Методологія наукової діяльності : навч. посіб. / за ред. Д. В. Чернілевського. Вінниця : Вид-во АМСКП, 2010. 484 с.

16. Миськів Г. В. Функціонування та розвиток кредитного ринку : дис. ... д-ра екон. наук : 08.00.08. Київ, 2016. 533 с.

17. Міжнародні стандарти з протидії відмиванню доходів та фінансуванню тероризму і розповсюдженню зброї масового знищення. URL: http://www.sdfm.gov.ua/content/file/ Site_docs/2012/22.03.2012/1.pdf

18. Мінфін створить робочі групи щодо оподаткування операцій із криптовалютами і постачання програмного забезпечення. URL: https:/gordonua.com/ukr/news/money/minfin-stvorit-robochi-grupi-z-opodatkuvannja-operatsij-zkriptovaljutami-i-postachannja-programnogo-zabezpechennja410338.html

19. Невиконані рекомендації FATF та чергова «жовта картка» для України. URL: https://www.unian.ua/politics/2383128nevikonani-rekomendaciji-fatf-ta-chergova-zhovta-kartka-dlyaukrajini.htm

20. Посібник FATF «Ризики відмивання коштів та фінансування тероризму через комерційні веб-сайти та платіжні системи Інтернету». URL: http://www.sdfm.gov.ua/content/File/ Site_docs/2008/161208/Pay-sys.pdf

21. Посібник FATF «Стратегії оцінки ризиків відмивання коштів та фінансування тероризму». URL: http://www.sdfm.gov. ua/content/File/Site_docs/2009/Strategij.pdf

22. Посібник щодо застосування підходу, що ґрунтується на оцінці ризиків відмивання коштів та фінансування тероризму в сфері надання грошових послуг. URL: http://www.sdfm.gov. ua/articles.php?cat_id=227\&art_id=1110\&lang $=u k$

23. Посібник щодо застосування підходу, що ґрунтується на оцінці ризику відмивання коштів та фінансування тероризму «Принципи та процедури для брокерів по операціям 3 нерухомістю». URL: http://www.sdfm.gov.ua/articles.php?cat_ id=227\&art_id=989\&lang=uk

24. Посібник щодо застосування підходу, що ґрунтується на оцінці ризику відмивання коштів та фінансування тероризму. Принципи та процедури для торговців дорогоцінними металами та дорогоцінним камінням // Державна служба фінансового моніторингу України. URL: http://www.sdfm.gov.ua/articles. php?cat_id=227\&art_id=988\&lang=uk

25. Про затвердження Положення про Державну службу фінансового моніторингу України : Постанова Кабінету Міністрів України від 29.07.2015 № 537 // База даних «Законодавство України» / Верховна Рада України. URL: http://zakon5.rada.gov. ua/laws/show/537-2015-п

26. Про реалізацію Стратегії розвитку системи запобігання та протидії легалізації (відмиванню) доходів, одержаних злочинним шляхом, фінансуванню тероризму та фінансуванню розповсюдження зброї масового знищення на період до 2020 року : Розпорядження КМУ від 30.08.2017 № 601-р // База даних «Законодавство України» / Верховна Рада України. URL: http:// zakon5.rada.gov.ua/laws/show/601-2017-p.

27. Про схвалення Концепції розвитку системи запобігання та протидії легалізації (відмиванню) доходів, одержаних злочинним шляхом, і фінансуванню тероризму на 2005-2010 рр. : Розпорядження Кабінету Міністрів України від 03.08.2005 № 315-р // Офіційний вісник України. 2005. № 32. Ст. 1951.

28. Про схвалення Стратегії розвитку системи запобігання та протидії легалізації (відмиванню) доходів, одержаних злочинним шляхом, фінансуванню тероризму та фінансуванню розповсюдження зброї масового знищення на період до 2020 року : Розпорядження Кабінету Міністрів України від 30.12.2015 № 1407-р // База даних «Законодавство України» / Верховна Рада України. URL: http://zakon2. rada.gov.ua/laws/show/1407-2015-p

29. Рекомендації FATF міжнародні стандарти боротьби з відмиванням коштів, фінансуванням тероризму і розповсюдженням зброї масового знищення методологія з оцінки технічної відповідності рекомендаціям FATF та ефективності систем протидії відмиванню коштів та боротьби з фінансуванням тероризму правила та процедури 5-го раунду взаємних оцінок комітетом MONEYVAL. FATF., EUACl, 2018. 260 с.

30. Румельт Р. Хорошая стратегия, плохая стратегия. В чем отличие и почему это важно. М. : Манн, Иванов и Фербер, 2014. 448 c.

31. Стрельников К. А. Государственно-правовая стратегия как категория современной юридической науки. Государственная власть и местное самоуправление. 2009. № 8. С. 3-4.

32. Стрижиченко К. А. Формування концепції регулювання фінансового ринку України. Бізнес Інформ. 2014. № 10. С. 324-330.

33. Чмутова І. М., Ткачова Є. О. Фінансова стійкість банку як індикатор ризику відмивання коштів та фінансування. Економіка і суспільство. 2018. № 14. С. 867-875. 
34. Чубенко А. Г. Методика проведення оцінки ризиків відмивання коштів та фінансування тероризму. Український вимір // Збірка матеріалів спільного міжнародного семінару ОБСЄ та Держфінмоніторингу на тему: «Впровадження національної оцінки ризиків відмивання коштів та фінансування тероризму як елементу державної політики детінізації економіки України» (м. Київ, 25 листоп. 2014 р.). Київ, 2014. С. 88-104.

35. Vnukova N., Hontar D., Andriichenko Zh. International Preconditions for Development the Basics of a Concept of Riskoriented System on Combating Money Laundering and the Financing of Terrorism and Proliferation // Modern Management: Economy and Administration : monograph. Opole : The Academy of Management and Administration in Opole, 2018. P. 37-44.

\section{REFERENCES}

Andriichenko, Zh. O. "Vyznachennia napriamiv instytutsiinykh zmin dlia zabezpechennia efektyvnoho funktsionuvannia ryzyk-oriientovanoho pidkhodu u sferi finansovoho monitorynhu" [Determining the directions of institutional change to ensure the effective functioning of the risk-oriented approach in the field of financial monitoring]. Hlobalni ta natsionalni problemy ekonomiky. 2017. http://globalnational.in.ua/issue-17-2017

Andriichenko, Zh. O., and Litvinova, S. O. "Statystychne obgruntuvannia neobkhidnosti zaprovadzhennia ryzyk-oriientovanoho pidkhodu u sferi finansovoho monitorynhu v Ukraini" [Statistical justification for the need to implement a risk-oriented approach in the field of financial monitoring in Ukraine]. Problemy $i$ perspektyvy rozvytku pidpryiemnytstva, no. 2 (17) (2017): 49-55.

Bacho, R. I. "Formuvannia kontseptsii rozvytku rynkiv nebankivskykh finansovykh posluh Ukrainy" [Formation of the concept of development of the markets of non-bank financial services of Ukraine]. Hlobalni ta natsionalni problemy ekonomiky. 2016. http://global-national.in.ua/archive/13-2016/132.pdf

Chmutova, I. M., and Tkachova, Ye. O. "Finansova stiikist banku yak indykator ryzyku vidmyvannia koshtiv ta finansuvannia" [Financial stability of the bank as an indicator of risk of money laundering and financing]. Ekonomika i suspilstvo, no. 14 (2018): 867-875.

Chubenko, A. H. "Metodyka provedennia otsinky ryzykiv vidmyvannia koshtiv ta finansuvannia teroryzmu. Ukrainskyi vymir" [Methodology for assessing the risks of money laundering and terrorist financing. Ukrainian dimension]. Vprovadzhennia natsionalnoi otsinky ryzykiv vidmyvannia koshtiv ta finansuvannia teroryzmu iak elementu derzhavnoi polityky detinizatsii ekonomiky Ukrainy. Kyiv, 2014. 88-104.

Danilov, Yu. A., Abramov, A. Ye., and Buklemishev, O. V. Reforma finansovykh rynkov i nebankovsogo finansovogo sektora [Reform of financial markets and non-banking financial sector]. Moscow: RANKhiGS, 2017.

"Holova Derzhavnoi sluzhby finansovoho monitorynhu Ukrainy nadav interviu Natsionalnomu informatsiinomu ahentstvu Ukrainy "UKRINFORM»" [The head of the State Financial Monitoring Service of Ukraine gave an interview to the National Information Agency of Ukraine «UKRINFORM»]. http://sdfm.gov.ua/news. php?news_id $=3490$ \&lang $=$ uk

Hlushchenko, O. O., and Semehen, I. B. Antylehalizatsiinyi finansovyi monitorynh: ryzyk-oriientovanyi pidkhid [Anti-legal financial monitoring: risk-oriented approach]. Kyiv: UBS NBU, 2014.

"Kerivnytstvo FATF shchodo vykorystannia ryzyk-oriientovanoho pidkhodu dlia bankivskoho sektora" [FATF Guide on using a risk-oriented approach for the banking sector]. http://www.sdfm. gov.ua/content/file/Site_docs/2016/20160805/rek\%201.pdf
"Kerivnytstvo FATF shchodo zastosuvannia ryzyk-oriientovanoho pidkhodu do peredplachenykh kartok, mobilnykh platezhiv i posluh onlain-platezhiv" [FATF Guide to applying a risk-based approach to prepaid cards, mobile payments and online payment services]. http://www.fatf-gafi.org/publications/fatfrecommendations/documents/rba-npps-2013.html

"Kerivnytstvo po zastosuvanniu ryzyk-oriientovanoho pidkhodu "Virtualni valiuty»" [Guidance on the application of the riskoriented approach «Virtual Currencies»]. http://www.sdfm.gov.ua/ content/file/Site_docs/2016/20160805/rek\%202.pdf

[Legal Act of Ukraine] (2005)

[Legal Act of Ukraine] (2015). http://zakon2.rada.gov.ua/ laws/show/1407-2015-p

[Legal Act of Ukraine] (2015). http://zakon5.rada.gov.ua/ laws/show/537-2015-п

[Legal Act of Ukraine] (2017). http://zakon5.rada.gov.ua/ laws/show/601-2017-p

"Minfin stvoryt robochi hrupy shchodo opodatkuvannia operatsii iz kryptovaliutamy i postachannia prohramnoho zabezpechennia" [The Ministry of Finance will set up working groups on taxation of cyber-securities transactions and software supply]. https://gordonua.com/ukr/news/money/-minfin-stvorit-robochigrupi-z-opodatkuvannja-operatsij-z-kriptovaljutami-i-postachannja-programnogo-zabezpechennja-410338.html

"Mizhnarodni standarty z protydii vidmyvanniu dokhodiv ta finansuvanniu teroryzmu i rozpovsiudzhenniu zbroi masovoho znyshchennia" [International standards for combating money laundering and terrorist financing and the proliferation of weapons of mass destruction]. http://www.sdfm.gov.ua/content/file/ Site_docs/2012/22.03.2012/1.pdf

Metodolohiia naukovoi diialnosti [Methodology of scientific activity]. Vinnytsia: Vyd-vo AMSKP, 2010.

Myskiv, H. V. "Funktsionuvannia ta rozvytok kredytnoho rynku" [Functioning and development of the credit market]: dys. ... d-ra ekon. nauk:08.00.08, 2016.

"Nevykonani rekomendatsii FATF ta cherhova «zhovta kartka» dlia Ukrainy" [FATF's unfulfilled recommendations and another «yellow card» for Ukraine]. https://www.unian.ua/politics/2383128nevikonani-rekomendaciji-fatf-ta-chergova-zhovta-kartka-dlyaukrajini.html

"Posibnyk FATF «Ryzyky vidmyvannia koshtiv ta finansuvannia teroryzmu cherez komertsiini veb-saity ta platizhni systemy Internetu»" [FATF Manual on Money Laundering and Terrorist Financing through Commercial Websites and Internet Payment Systems]. http:// www.sdfm.gov.ua/content/File/Site_docs/2008/161208/Pay-sys.pdf

"Posibnyk FATF «Stratehii otsinky ryzykiv vidmyvannia koshtiv ta finansuvannia teroryzmu»" [FATF Manual «Money Laundering and Terrorist Financing Strategies»]. http://www.sdfm.gov.ua/ content/File/Site_docs/2009/Strategij.pdf

"Posibnyk shchodo zastosuvannia pidkhodu, shcho gruntuietsia na otsintsi ryzykiv vidmyvannia koshtiv ta finansuvannia teroryzmu v sferi nadannia hroshovykh posluh" [Guidance on the application of an approach based on the assessment of money laundering and terrorist financing risks in the provision of money services]. http://www.sdfm.gov.ua/articles.php?cat_id=227\&art_ id $=1110$ \&lang $=u k$

"Posibnyk shchodo zastosuvannia pidkhodu, shcho gruntuietsia na otsintsi ryzyku vidmyvannia koshtiv ta finansuvannia teroryzmu «Pryntsypy ta protsedury dlia brokeriv po operatsiiam z nerukhomistiu»" [Guidelines for applying a risk-based approach to money laundering and terrorist financing «Principles and Procedures for Real Estate Brokers»]. http://www.sdfm.gov.ua/articles. php?cat_id=227\&art_id=989\&lang=uk 
"Posibnyk shchodo zastosuvannia pidkhodu, shcho gruntuietsia na otsintsi ryzyku vidmyvannia koshtiv ta finansuvannia teroryzmu. Pryntsypy ta protsedury dlia torhovtsiv dorohotsinnymy metalamy ta dorohotsinnym kaminniam" [Guidance on the application of a risk-based approach to money laundering and terrorist financing. Principles and procedures for traders of precious metals and precious stones]. Derzhavna sluzhba finansovoho monitorynhu Ukrainy. http://www.sdfm.gov.ua/articles.php?cat_ $\mathrm{id}=227$ \&art_id=988\&lang=uk

Rekomendatsii FATF mizhnarodni standarty borotby z vidmyvanniam koshtiv, finansuvanniam teroryzmu i rozpovsiudzhenniam zbroi masovoho znyshchennia metodolohiia z otsinky tekhnichnoi vidpovidnosti rekomendatsiiam FATF ta efektyvnosti system protydii vidmyvanniu koshtiv ta borotby z finansuvanniam teroryzmu pravyla ta protsedury 5-ho raundu vzaiemnykh otsinok komitetom MONEYVAL [FATF Recommendations International Standards for combating money laundering, terrorist financing and proliferation of weapons of mass destruction A methodology for assessing technical compliance with the FATF recommendations and the effectiveness of anti-money laundering and anti-terrorist financing systems are the rules and procedures of the 5th round of mutual evaluations by the MONEYVAL committee]. FATF., EUACI, 2018.

Rumelt, R. Khoroshaya strategiya, plokhaya strategiya. V chem otlichiye i pochemu eto vazhno [Good strategy, bad strategy. What is the difference and why it is important]. Moscow: Mann, 2014.

Strelnikov, K. A. "Gosudarstvenno-pravovaya strategiya kak kategoriya sovremennoy yuridicheskoy nauki" [State-legal strategy as a category of modern legal science]. Gosudarstvennaya vlast imestnoye samoupravleniye, no. 8 (2009): 3-4.

Stryzhychenko, K. A. "Formuvannia kontseptsii rehuliuvannia finansovoho rynku Ukrainy" [Formation of the concept of regulation of the financial market of Ukraine]. Biznes Inform, no. 10 (2014): 324-330.
Vnukova, N. M. "Ryzyk-oriientovanyi pidkhid subiektiv pervynnoho finansovoho monitorynhu do klasyfikatsii kliientiv" [Riskoriented approach of subjects of initial financial monitoring to the classification of clients]. Suchasni problemy finansovoho monitorynhu. Kharkiv: KhNEU im. S. Kuznetsia; Ekskliuzyv, 2018. 20-24.

Vnukova, N. M., Kolodiziev, O. M., and Chmutova, I. M. "Analiz mizhnarodnoho dosvidu zastosuvannia ryzyk-oriientovanoho pidkhodu u sferi protydii vidmyvanniu koshtiv, finansuvanniu teroryzmu ta rozpovsiudzhennia zbroi masovoho znyshchennia" [An analysis of international experience in applying a risk-based approach to $A M L$, terrorist financing and proliferation of weapons of mass destruction]. Hlobalni ta natsionalni problemy ekonomiky. 2017. http://globalnational.in.ua/issue-17-2017

Vnukova, N., Hontar, D., and Andriichenko, Zh. "International Preconditions for Development the Basics of a Concept of Risk-oriented System on Combating Money Laundering and the Financing of Terrorism and Proliferation". In Modern Management: Economy and Administration, 37-44. Opole: The Academy of Management and Administration in Opole, 2018.

Yehorycheva, S. B. "Vprovadzhennia ryzyk-oriientovanoho nahliadu u systemi finansovoho monitorynhu v Ukraini“ [Implementation of risk-based supervision in the system of financial monitoring in Ukraine]. Suchasni problemy finansovoho monitorynhu. Kharkiv: KhNEU im. S. Kuznetsia; Ekskliuzyv, 2018. 5-8.

"Zvit FATF «Ryzyky finansuvannia teroryzmu»" [FATF Report «The Risks of Terrorist Financing»]. http://www.sdfm.gov.ua/content/file/Site_docs/2016/20160727/Zmist1.pdf

"Zvit pro provedennia natsionalnoi otsinky ryzykiv u sferi zapobihannia ta protydii lehalizatsii (vidmyvanniu) dokhodiv, oderzhanykh zlochynnym shliakhom, ta finansuvanniu teroryzmu" [Report on conducting a national risk assessment in the area of prevention and counteraction to the legalization (laundering) of proceeds from crime and terrorist financing]. http://www.sdfm. gov.ua/content/file/Site_docs/2016/20161125/zvit_ukr.pdf 